\title{
31. PETROLEUM-GENERATING POTENTIAL OF SEDIMENT IN THE GULF OF CALIFORNIA ${ }^{1}$
}

\author{
J. W. Kendrick, ${ }^{2}$ Shell Development Company, Bellaire Research Center, Houston, Texas
}

\begin{abstract}
Sediments from the Gulf of California contain sufficient amounts of thermally reactive organic matter to be considered fair-to-good potential petroleum source rocks. While sediments deposited within the present oxygen-minimum zone have the greatest amounts of organic matter, those deposited below the oxygen-minimum contain sufficient organic matter to be considered potential source rocks. The organic matter in the sediment is almost exclusively marine, Type II kerogen. Different techniques of determining kerogen composition produce generally compatible answers, although pyrolysis gives somewhat misleading results. Elemental analysis of the kerogen and vitrinite reflectance measurements indicate that the organic matter is not buried to sufficiently great depth for significant petroleum generation, despite the high temperature gradients.
\end{abstract}

\section{INTRODUCTION}

The objectives of this study are to characterize the amount and composition of organic matter preserved in Gulf of California sediment, especially as the sediment is related to the oxygen-minimum layer, and to determine the effect of regional heat flow on the thermal maturation of organic matter. We selected sediment samples from three locations cored during Leg 64 . Sites 478 and 479 lie in the Guaymas Basin of the central Gulf of California. Hole 478 is in 1889 meters of water, below the present oxygen-minimum; Hole 479 was drilled in 747 meters of water, within the oxygen-minimum. Thus, we can compare the effects of the oxygen-minimum on the sedimentation of organic matter. The sediment is mainly Quaternary. In Hole 479, there may be a hiatus at about 390 meters, below which lie late Pliocene sediments (Y. Matoba, personal communication, 1979). We also examined samples from Hole 476, which is near the mouth of the Gulf, on the continental margin of Baja California. This hole bottomed in granitic and metamorphic rocks; above lies a thin bed of early Pliocene or older sediment, rich in organic matter. We were interested in determining the petroleum-generating potential and kerogen composition of this layer.

For this study, we employed the techniques which we normally use to evaluate petroleum source-rock potential and temperature history (Hood et al., 1976). We used the organic carbon content $\left(\mathrm{C}_{\text {org }}\right)$ and the hydrocarbons evolved during pyrolysis to determine the total amount of organic matter and the amount of thermally reactive organic matter, respectively. We measured the reflectance of vitrinite to determine the thermal maturity of the organic matter. We characterized the composition of the organic matter by several techniques, including an optical identification of macerals and a comparison of the pyrolysis-hydrocarbon yield with organic carbon content. We also isolated the kerogen of selected samples to make an elemental analysis of the kerogen.

\footnotetext{
${ }^{1}$ Curray, J. R., Moore, D. G., et al., Init. Repts. DSDP, 64: Washington (U.S. Govt. Printing Office).

2 Present address: Shell Oil Company, Houston, Texas.
}

\section{AMOUNT OF ORGANIC MATTER}

To evaluate the petroleum-generating potential, we determined the amount of organic carbon, or noncarbonate carbon, in the sediment. As a general rule, we regard 1.0 to $1.5 \%$ organic carbon as the minimum amount necessary to consider a sediment a potential petroleum source rock. The organic carbon content does not indicate, however, the proportion of organic matter convertible to petroleum. The thermal reactivity of organic matter is influenced by its composition and temperature history. Consequently, we use pyrolysis to estimate the amount of petroleum-like products that can be generated during heating. We used a pyrolysis-flameionization-detector technique (P-FID): The sample is heated to $750^{\circ} \mathrm{C}$, and the hydrocarbon yield is measured with a flame ionization detector. A sediment's pyrolysis-hydrocarbon yield must exceed $0.3 \%$ before it can be considered a potential source rock.

The samples contain 0.43 to $3.86 \%$ organic carbon (Table 1), with a median value of $2.5 \%$. These samples

Table 1. Amount of organic matter.

\begin{tabular}{lcccc}
\hline $\begin{array}{c}\text { Sample } \\
\text { (interval in cm) }\end{array}$ & $\begin{array}{c}\text { Sub-bottom } \\
\text { depth (m) }\end{array}$ & $\begin{array}{c}\mathrm{C}_{\text {org }}(\%) \\
\text { (from P-FID) }(\%)\end{array}$ & $\begin{array}{c}\text { Hydrocarbon Yield } \\
\text { (fC (\%)) }\end{array}$ \\
\hline $\begin{array}{c}\text { Corg }(\%) \\
476-3-4,133-140\end{array}$ & 24.4 & 3.04 & 0.98 & 0.32 \\
$476-7-6,110-117$ & 65.1 & 1.79 & 0.33 & 0.18 \\
$476-11-4,121-126$ & 100.2 & 2.15 & 0.56 & 0.26 \\
$476-19-1,145-150$ & 172.0 & 1.10 & 0.22 & 0.20 \\
$476-21-4,70-74$ & 194.7 & 3.23 & 0.97 & 0.30 \\
$478-2-5,120-125$ & 10.7 & 3.65 & 1.50 & 0.41 \\
$478-6-3,143-148$ & 46.0 & 1.61 & 0.44 & 0.27 \\
$478-13-2,120-126$ & 110.7 & 2.51 & 1.00 & 0.40 \\
$478-16-4,125-131$ & 142.3 & 1.34 & 0.18 & 0.13 \\
$478-28-4,130-137$ & 246.8 & 2.22 & 0.72 & 0.32 \\
$478-35-5,120-127$ & 305.2 & 0.43 & 0.05 & 0.12 \\
$479-3-2,108-112$ & 16.6 & 3.07 & 1.22 & 0.40 \\
$479-7-5,130-140$ & 57.9 & 2.54 & 0.87 & 0.34 \\
$479-13-1,130-140$ & 108.9 & 3.51 & 1.59 & 0.45 \\
$479-17-5,140-150$ & 153.0 & 2.36 & 0.73 & 0.31 \\
$479-22-5,110-119$ & 200.1 & 2.81 & 0.92 & 0.33 \\
$479-29-5,140-150$ & 267.0 & 2.82 & 0.97 & 0.34 \\
$479-34-5,130-135$ & 314.3 & 3.13 & 1.22 & 0.39 \\
$479-39-4,120-130$ & 360.3 & 3.86 & 2.08 & 0.54 \\
$479-43-1,135-140$ & 393.9 & 2.65 & 1.25 & 0.47 \\
$479-47-4,120-130$ & 463.3 & 1.13 & 0.24 & 0.21 \\
\hline
\end{tabular}


have hydrocarbon yields from P-FID ranging from 0.05 to $2.08 \%$, with a median value of about $0.9 \%$. All but four of the samples have pyrolysis yields great enough to be considered potential source rocks. The four samples of nonsource rocks have less than $1.5 \%$ organic carbon. Consequently, if we use the upper limit of organic carbon values we believe necessary to consider a sediment a potential source rock, we obtain indications of petroleum-generating potential compatible with pyrolysis results.

Our results and shipboard organic carbon data indicate that-except for some laminated mudstones below 400 meters, whose organic carbon values diminish to less than $2 \%$-the sediments in Hole 479 have uniform organic carbon contents. (av. $\cong 2.9 \%$ ). Paleontological studies by Y. Matoba suggest that the mudstones are late Pliocene and are disconformable with the overlying sediment. Quaternary sediments in Holes $\mathbf{4 7 6}$ and 478 contain somewhat less organic carbon, averaging about $2.0 \%$; the sediments also vary more in their content organic matter than the sediment in Hole 479. Pliocene sediments in Hole 476 exhibit still lower values of organic carbon-from 1.0 to $1.5 \%$. But at the base of the sedimentary column, a thin layer of laminated, glauconitic mudstone contains 3 to $7 \%$ organic carbon.

Although the content of organic matter is lower in Hole 478, many sediments contain sufficient organic matter to be considered potential source rocks. Therefore, the deposition of potential source rocks does not appear to be limited to those areas where the present oxygen-minimum layer impinges on the seafloor.

\section{COMPOSITION OF ORGANIC MATTER}

We characterized the kerogen composition by visual kerogen description, elemental analysis, and pyrolysis. The use of several techniques provided an important comparison of various kerogen typing methods.

\section{Maceral Composition}

We performed the visual kerogen analysis during the measurement of vitrinite reflectance; we described the maceral composition according to a four-part classification. Hydrogen-rich organic matter is classified as liptinite or amorphous kerogen, depending on whether it is structured (algae, spores, and so forth) or structureless, respectively. Vitrinite is hydrogen-poor organic matter, typically derived from woody land plants. Inertinite comprises thermally inert macerals, such as fusinite, semifusinite, and micrinite.

The visual kerogen analysis (Table 2) indicates that the organic matter is predominantly amorphous, with secondary amounts of liptinite. Amorphous kerogen is a common constituent in the kerogens of marine sediment and we believe that its origin is aquatic. The structureless appearance of the kerogen could reflect algal material without any original form or algae subsequently altered by bacteria. The liptinite comprises small $(\cong 2$ $\mu \mathrm{m})$ particles that fluoresce yellow under ultraviolet light. We believe that the origin of the liptinite is algal as well, but we cannot account for the difference in appearance between liptinite and amorphous kerogen, even though we have inferred a similar origin for the two macerals. Vitrinite and inertinite constitute less than $2 \%$ of the kerogen, except in Sample 478-16-4, 125-131 cm, where they make up 15 to $20 \%$. The small component of terrigenous organic matter in this sediment contrasts with our examination of deep-sea sediment elsewhere (Hood et al., 1976; Kendrick, 1979; Kendrick et al., 1979). The smaller proportions of terrigenous material in the Gulf sediment could reflect the restricted contribution of such material in this arid region. Alternatively, the rate of supply of terrigenous organic matter may be similar to that in other regions, but its effect may be diluted by the high accumulation rates of marine organic matter.

The kerogen in Sample 476-21-4, 70-74 cm differs from that in the other samples. It consists of small bodies $(<10 \mu \mathrm{m})$ exhibiting little or no fluorescence under ultraviolet light. The reflectance of this material $(\sim 0.2 \%)$ is less than that of the vitrinite in superjacent samples $(\sim 0.3 \%)$ but greater than that of amorphous kerogen $(\sim 0.1 \%)$. We believe the material is slightly altered amorphous kerogen. Pyrolysis results support this conclusion.

Sample 476-21-4, 70-74 cm represents the basal clays in Hole 476, which are rich in organic matter. Although the sample contains only $3.2 \% \mathrm{C}_{\mathrm{org}}$, a value similar to those of many others in our sample set, shipboard analyses indicate that this claystone can contain in excess of $7 \% \mathrm{C}_{\text {org }}$. The deposit overlies granitic and metamorphic rocks and is associated with phosphatic and glauconitic sediment. Associated sands are well sorted, indicating some current energy. Consequently, although this deposit lies in 2400 meters of water, it might have been deposited in much shallower water, possibly in a shelf environment. It is difficult to conclude how extensive this potential source rock may be. It was not encountered in Hole 475 , which seems to have penetrated the equivalent interval in still deeper water.

\section{Elemental Analysis}

We isolated the kerogens from several sediment samples to determine their elemental composition. Tissot et al. (1974) showed that the $\mathrm{H} / \mathrm{C}$ and $\mathrm{O} / \mathrm{C}$ ratios of kerogens can distinguish different types of organic matter and reveal changes in chemical composition that result from diagenetic and thermal alteration of the kerogen.

We prepared the kerogen concentrates by treating the chloroform-methanol-extracted samples with hydrochloric and hydrofluoric acid. The residue comprises kerogen and pyrite. With a few exceptions, the kerogen concentrates came from Hole 479. The analytical results are reported in Table 3, and the atomic $\mathrm{H} / \mathrm{C}$ and $\mathrm{O} / \mathrm{C}$ ratios are displayed on a van Krevelen diagram (Fig. 1). The curved lines in Figure 1 represent the compositional paths followed by different kerogen types during thermal alteration. Most of the kerogens from Leg 64 cluster to the right of the evolution path for Type II kerogen. Type II kerogen represents autochthonous, usually marine, organic matter deposited in a reducing environ- 
Table 2. Vitrinite reflectance and maceral composition of kerogen.

\begin{tabular}{|c|c|c|c|c|c|c|c|c|c|}
\hline \multirow[b]{2}{*}{$\begin{array}{c}\text { Sample } \\
\text { (interval in } \mathrm{cm} \text { ) }\end{array}$} & \multirow[b]{2}{*}{$\begin{array}{l}\text { Sub-bottom } \\
\text { Depth }(\mathrm{m})\end{array}$} & \multirow[b]{2}{*}{ Age } & \multicolumn{3}{|c|}{ Vitrinite Reflectance } & \multicolumn{4}{|c|}{ Maceral Composition ${ }^{\mathrm{a}}$} \\
\hline & & & $\begin{array}{l}\text { Numb } \\
\text { Observa }\end{array}$ & et of ef $\mathrm{b}$ & Mean $R_{0}^{c}(\%)$ & Amorphous & Liptinite & Vitrinite & Inertinite \\
\hline $476-3-4,133-140 \mathrm{a}$ & 24.4 & Quaternary & A & 46 & $0.33 \pm 0.02$ & 89 & 10 & $<1$ & $<1$ \\
\hline & & & $\mathrm{x}$ & 50 & $0.34 \pm 0.02$ & & & & \\
\hline $476-3-4,133-140 b$ & 24.4 & Quaternary & $\stackrel{A}{x}$ & $\begin{array}{l}46 \\
50\end{array}$ & $\begin{array}{l}0.23 \pm 0.02 \\
0.25 \pm 0.02\end{array}$ & 92 & 6 & 1 & $<1$ \\
\hline $476-7-6,110-117$ & 65.1 & Quaternary & $\mathrm{x}$ & 50 & $0.36 \pm 0.03$ & 97 & 2 & $<1$ & $<1$ \\
\hline $476-11-4,121-126$ & 100.2 & Pliocene & $\stackrel{A}{x}$ & $\begin{array}{l}47 \\
50\end{array}$ & $\begin{array}{l}0.30 \pm 0.03 \\
0.32 \pm 0.04\end{array}$ & 92 & 7 & $<1$ & $<1$ \\
\hline $476-19-1,145-150$ & 172.0 & Pliocene & $\stackrel{A}{x}$ & $\begin{array}{l}46 \\
50\end{array}$ & $\begin{array}{l}0.32 \pm 0.03 \\
0.34 \pm 0.03\end{array}$ & 98 & 1 & $<1$ & $<1$ \\
\hline $476-21-4,70-74$ & 194.7 & ? & & & & 99 & $<1$ & - & - \\
\hline $478-2-5,120-125$ & 10.7 & Quaternary & A & 18 & $0.27 \pm 0.04$ & 90 & 9 & $<1$ & $<1$ \\
\hline $478-6-3,143-148$ & 46.0 & Quaternary & $\mathrm{x}$ & 34 & $0.44 \pm 0.06$ & 94 & 5 & $<1$ & $<1$ \\
\hline $478-13-2,120-126 a$ & 110.7 & Quaternary & A & 50 & $0.26 \pm 0.02$ & 90 & 7 & 1 & 2 \\
\hline $478-13-2,120-126 b$ & 110.7 & Quaternary & $\stackrel{A}{x}$ & $\begin{array}{l}16 \\
18\end{array}$ & $\begin{array}{l}0.32=0.03 \\
0.35=0.05\end{array}$ & 92 & 7 & $<1$ & $<1$ \\
\hline $478-16-4,125-131 a$ & 142.3 & Quaternary & $\mathrm{x}$ & 31 & $0.66 \pm 0.09$ & 75 & 5 & 14 & 6 \\
\hline $478-16-4,125-131 \mathrm{~b}$ & 142.3 & Quaternary & A & so & $0.32 \pm 0.02$ & 83 & 2 & 10 & 5 \\
\hline $478-28-4,130-137$ & 246.8 & Quaternary & $x$ & 13 & $0.50 \pm 0.13$ & 89 & 10 & $<1$ & $<1$ \\
\hline $478-35-5,120-127$ & 305.2 & Quaternary & A & 50 & $0.31 \pm 0.02$ & 95 & 2 & 1 & 2 \\
\hline $479-3-2,108-112$ & 16.6 & Quaternary & & & barren & 95 & 5 & - & - \\
\hline $479.7-5,130-140$ & 57.9 & Quaternary & A & 50 & $0.23 \pm 0.03$ & 92 & 6 & 1 & 1 \\
\hline $479-13-1,130-140$ & 108.9 & Quaternary & A & 50 & $0.25 \pm 0.02$ & 95 & 3 & i & I \\
\hline $479-17-5,140-150$ & 153.0 & Quaternary & $\stackrel{A}{x}$ & $\begin{array}{l}44 \\
50\end{array}$ & $\begin{array}{l}0.22 \pm 0.02 \\
0.27 \pm 0.04\end{array}$ & 95 & 3 & 1 & 1 \\
\hline $479-22-5,110-119$ & 200.1 & Quaternary & $\mathrm{x}$ & 11 & $0.37 \pm 0.06$ & 92 & 7 & $<1$ & $<1$ \\
\hline $479-29-5,140-150$ & 267.0 & Quaternary & A & 37 & $0.27 \pm 0.03$ & 94 & 5 & $<1$ & $<1$ \\
\hline $479-34-5,130-135$ & 314.3 & Quaternary & $x$ & 16 & $0.41 \pm 0.06$ & 94 & 5 & $<1$ & $<1$ \\
\hline $479-39-4,120-130$ & 360.3 & Pliocene(?) & A & 17 & $0.28 \pm 0.04$ & 87 & 12 & $<1$ & $<1$ \\
\hline $479-43-1,135-140$ & 393.9 & Pliocene & $\stackrel{A}{X}$ & $\begin{array}{l}19 \\
23\end{array}$ & $\begin{array}{l}0.36 \pm 0.04 \\
0.43 \pm 0.08\end{array}$ & 96 & 3 & $<1$ & $<1$ \\
\hline $479-47-4,120-130$ & 436.9 & Quaternary & $\stackrel{A}{x}$ & $\begin{array}{l}18 \\
28\end{array}$ & $\begin{array}{l}0.30 \pm 0.03 \\
0.43 \pm 0.08\end{array}$ & 97 & 1 & 1 & 1 \\
\hline
\end{tabular}

Note: "a" and " $\mathrm{b}$ " in sample designations indicate subsamples.

a As a percentage of the kerogen.

" $X$ " represents the population of all vitrinite reflectance measurements; "A" represents the population of measurements interpreted

to be primary vitrinite.
c $\% R_{0}+95 \%$ confidence limit.

Table 3. Elemental analysis of kerogen concentrates.

\begin{tabular}{crrrrrrrrr}
\hline $\begin{array}{c}\text { Sample } \\
\text { (interval in cm) }\end{array}$ & $\begin{array}{c}\text { Depth } \\
\text { (m) }\end{array}$ & $\% \mathrm{C}$ & $\% \mathrm{H}$ & $\% \mathrm{~N}$ & $\% \mathrm{O}$ & $\% \mathrm{~S}$ & $\% \mathrm{Fe}$ & $\begin{array}{c}\mathrm{H} / \mathrm{C} \\
\text { (atomic) }\end{array}$ & $\begin{array}{c}\mathrm{O} / \mathrm{C} \\
\text { (atomic) }\end{array}$ \\
\hline $476-3-4,133-140$ & 24.4 & 40.6 & 4.3 & 2.7 & 15.2 & $\mathrm{NA}$ & $\mathrm{NA}$ & 1.27 & 0.28 \\
$478-13-2,120-126$ & 110.7 & 39.4 & 4.1 & 2.4 & 15.8 & $\mathrm{NA}$ & $\mathrm{NA}$ & 1.25 & 0.30 \\
$478-16-4,125-131$ & 142.3 & 23.0 & 1.9 & 1.3 & 9.9 & $\mathrm{NA}$ & $\mathrm{NA}$ & 0.99 & 0.32 \\
$479-7.5,130-140$ & 57.9 & 40.0 & 4.4 & 2.6 & 14.2 & 19.8 & 12.1 & 1.32 & 0.27 \\
$479-13-1,130-140$ & 108.9 & 46.5 & 5.0 & 2.4 & 16.2 & $\mathrm{NA}$ & $\mathrm{NA}$ & 1.29 & 0.26 \\
$479-17-5,140-150$ & 153.0 & 37.8 & 4.0 & 2.4 & 12.7 & 22.4 & 15.2 & 1.27 & 0.25 \\
$479-29-5,140-150$ & 267.0 & 35.2 & 3.8 & 2.2 & 10.8 & 25.3 & 18.7 & 1.30 & 0.23 \\
$479-39-4,120-130$ & 360.3 & 50.0 & 5.7 & 2.5 & 12.4 & 13.4 & 8.0 & 1.37 & 0.19 \\
$479-47-4,120-130$ & 436.9 & 24.3 & 2.4 & 1.4 & 7.0 & 33.7 & 25.6 & 1.19 & 0.22 \\
\hline
\end{tabular}

Note: $\mathrm{NA}=$ not analyzed.

ment (Tissot and Welte, 1978). Elemental analysis and visual examination thus provide consistent indications of kerogen type.

One kerogen concentrate, Sample 478-16-4, 125-131 $\mathrm{cm}$, has a composition differing considerably from the other samples. It is near the evolution path of Type III kerogen. This difference is explained by referring to the maceral composition of the sample (Table 2), which shows that it is the only sample containing a significant proportion of vitrinite and inertinite (15 to $20 \%$ ).

The thermal maturity of the sediment in the Gulf will be discussed later in this chapter; but we should note that the high $\mathrm{O} / \mathrm{C}$ ratios of the kerogen indicate that the kerogens are thermally very immature.

\section{Pyrolysis}

The proportion of organic matter thermally convertible to petroleum is a function of the kerogen's composition, especially its hydrogen content. Espitalié et al. (1977) and Kendrick (1979) have commented on the use of the ratio of pyrolysis hydrocarbon yield to organic carbon content as an index of the kerogen's H/C ratio. Bordenave et al. (1970) had defined similar ratios,

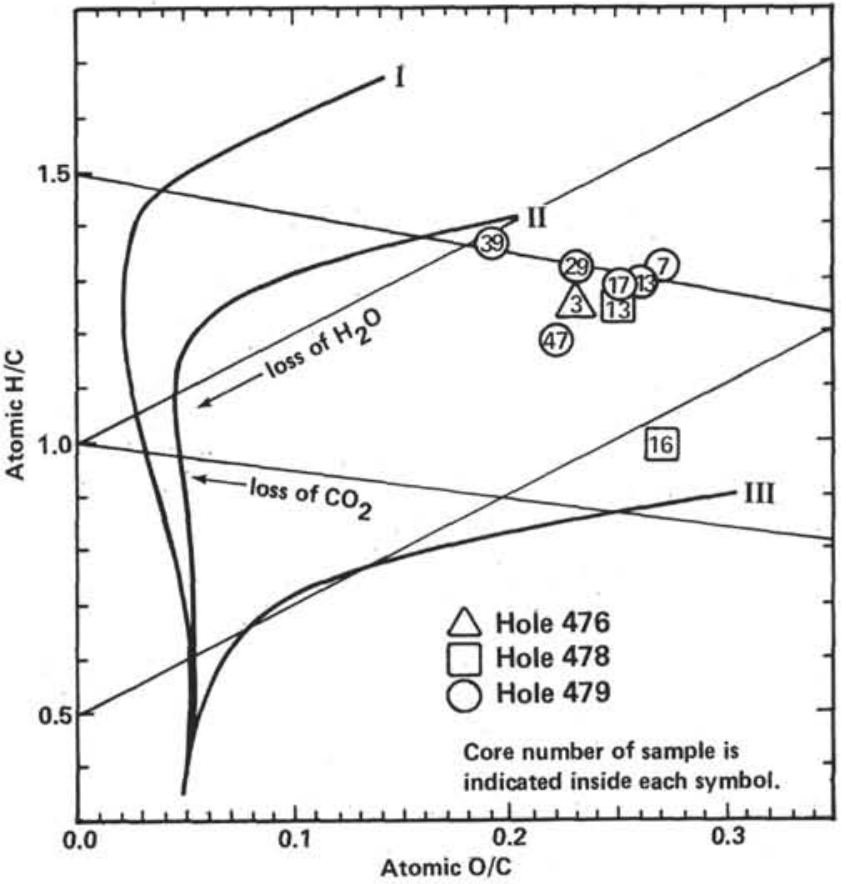

Figure 1. Van Krevelen diagram depicting kerogen composition of Leg 64 sediments.

relating the amount of volatile carbon $\left(\mathrm{C}_{V}\right)$ to total carbon $\left(C_{T}\right)$. Gransch and Eisma (1970) related the amount of residual carbon after pyrolysis $\left(\mathrm{C}_{R}\right)$ to total carbon $\left(C_{T}\right)$. The ratio of pyrolysis hydrocarbons to organic carbon (Table 1) should therefore provide indications of kerogen type similar to those provided by elemental composition on a van Krevelen diagram. 
The ratio of pyrolysis hydrocarbons to organic carbon for the Leg 64 samples exhibits considerable variation, ranging from 0.12 to 0.54 (Table 1). Applying published relations between pyrolysis yield per unit carbon and the hydrogen-to-carbon ratio (Espitalié et al., 1977; Kendrick, 1979) implies that the kerogens in this study have $\mathrm{H} / \mathrm{C}$ ratios between 0.75 and 1.3: i.e., that the $\mathrm{Leg}$ 64 kerogens contain Type II and Type III kerogens. Visual kerogen analyses and actual determinations of elemental composition, however, indicate that the kerogens are uniform in composition and mostly Type II.

The anomalous indications of kerogen composition provided by the pyrolysis technique seem to result from the effect of the mineral matrix on the pyrolysis yield. Espitalié et al. (1980) and Monin et al. (1980) presented evidence that the mineral matrix, particularly clay, retains a portion of the hydrocarbons generated during pyrolysis. The proportion of the pyrolysate retained by the rock is greatest for the rocks with the least amount of organic matter. As a result, the pyrolysis yield per unit carbon is related not only to kerogen composition but also to the content of organic matter. This effect of the mineral matrix is illustrated in Figure 2, where the pyrolysis yields of the Leg 64 sediment are plotted against organic carbon. The points define a trend in which the hydrocarbon yield approaches zero at about $1 \%$ organic carbon. Previously, such a pattern was interpreted to indicate the presence of thermally inert organic matter. The sediment in the Gulf of California, however, contains only minor amounts of inertinite, and, consequently, the effect of mineral matrix seems a more reasonable explanation for the unusually low pyrolysis yields in samples with little organic carbon.

By taking the slope of the line defined by the points in Figure 2, we can obtain an estimate of kerogen type-an

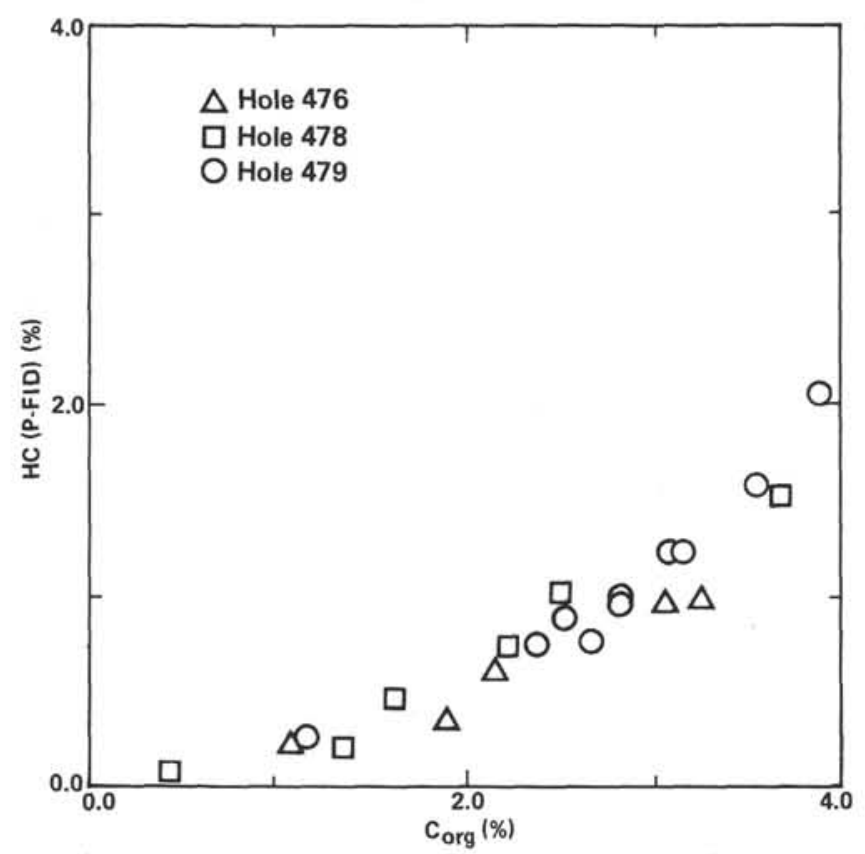

Figure 2. Plot of pyrolysis hydrocarbon yield versus organic carbon, Leg 64 samples. estimate minimizing the effect of hydrocarbon retention by the mineral matrix. The result is a pyrolysis yield per unit carbon of 0.63 , which corresponds to an $\mathrm{H} / \mathrm{C}$ ratio of about 1.3. This estimate is consistent with the actual measurements of $\mathrm{H} / \mathrm{C}$ (Table 3). Consequently, it appears that pyrolysis can describe kerogen composition, but the technique is limited by the need to analyze several samples. Direct determination of elemental kerogen composition does not require several samples, but it involves a lengthy procedure to isolate the kerogen from the rock matrix, making it a more difficult analysis.

\section{THERMAL MATURITY}

To determine the thermal maturity of the sediment, we measured the reflectance (in oil) of vitrinite (Table $2)$. For each sample, we have indicated the mean reflectance $\left(R_{0}\right)$ of all reflectance measurements and have denoted this population with "X." We have also indicated those values we interpret as primary, unreworked, vitrinite with "A." When we could not distinguish primary from reworked vitrinite or when there were too few readings of primary vitrinite to be meaningful, no "A" value was given.

In the three holes, the profiles of vitrinite reflectance versus depth vary considerably in quality (Fig. 3A-C). The samples from Hole 479 exhibit well-defined reflectance modes, increasing systematically with depth (Fig. 3C). The trend is better than any found in our previous studies of cores from Deep Sea Drilling Project. But in a second preparation of Sample 476-3-4, $133-140 \mathrm{~cm}$, we obtained a mean reflectance quite different from the first estimate (Table 2). The latter incident emphasizes the need for caution in interpreting the vitrinite reflectance data, even for holes where the data appear to be good. At low levels $(<0.5)$, vitrinite reflectance changes very slowly with increasing rank. The samples in this study come from a narrow depth range, which may be insufficient to establish an accurate trend of reflectance versus depth. Furthermore, the vitrinite in the Gulf sediment constitutes only about $1 \%$ of the total kerogen. The reflectance properties of vitrinite in these samples may not be the same as in a humic coal.

What can be said with reasonable certainty is that sediment from the three holes is thermally very immature and has not reached the stage of oil generation. The reflectance of primary vitrinite ranges from 0.22 to $0.36 \%$ whereas significant oil generation would not begin until about $0.5 \%$ vitrinite reflectance. The low level of maturity is confirmed by the previously reported analyses of elemental composition, which indicate that the sediment is still at an early stage of diagenesis.

Shipboard estimates of heat flow for Holes 476, 478, and 479 range from 2.4 to $2.8 \mu \mathrm{cal} \mathrm{cm}^{-2} \mathrm{~s}^{-1}$, typical of the average values for mid ocean ridge axes $(2.7 \mu \mathrm{cal}$ $\left.\mathrm{cm}^{-2} \mathrm{~s}^{-1}\right)$ and nearly twice the average for ocean basins $\left(1.3 \mu \mathrm{cal} \mathrm{cm} \mathrm{cm}^{-2} \mathrm{~s}^{-1}\right.$ [Langseth and Von Herzen, 1968]). Hole 479 , which penetrated 440 meters of sediment, reached formation temperatures of $50^{\circ} \mathrm{C}$, and the temperature gradient is about $0.1^{\circ} \mathrm{C} / \mathrm{m}\left(5.5^{\circ} \mathrm{F} / 100 \mathrm{ft}\right)$. Despite the high geothermal gradients in the holes, greater penetration would be necessary to reach the zone of pe- 

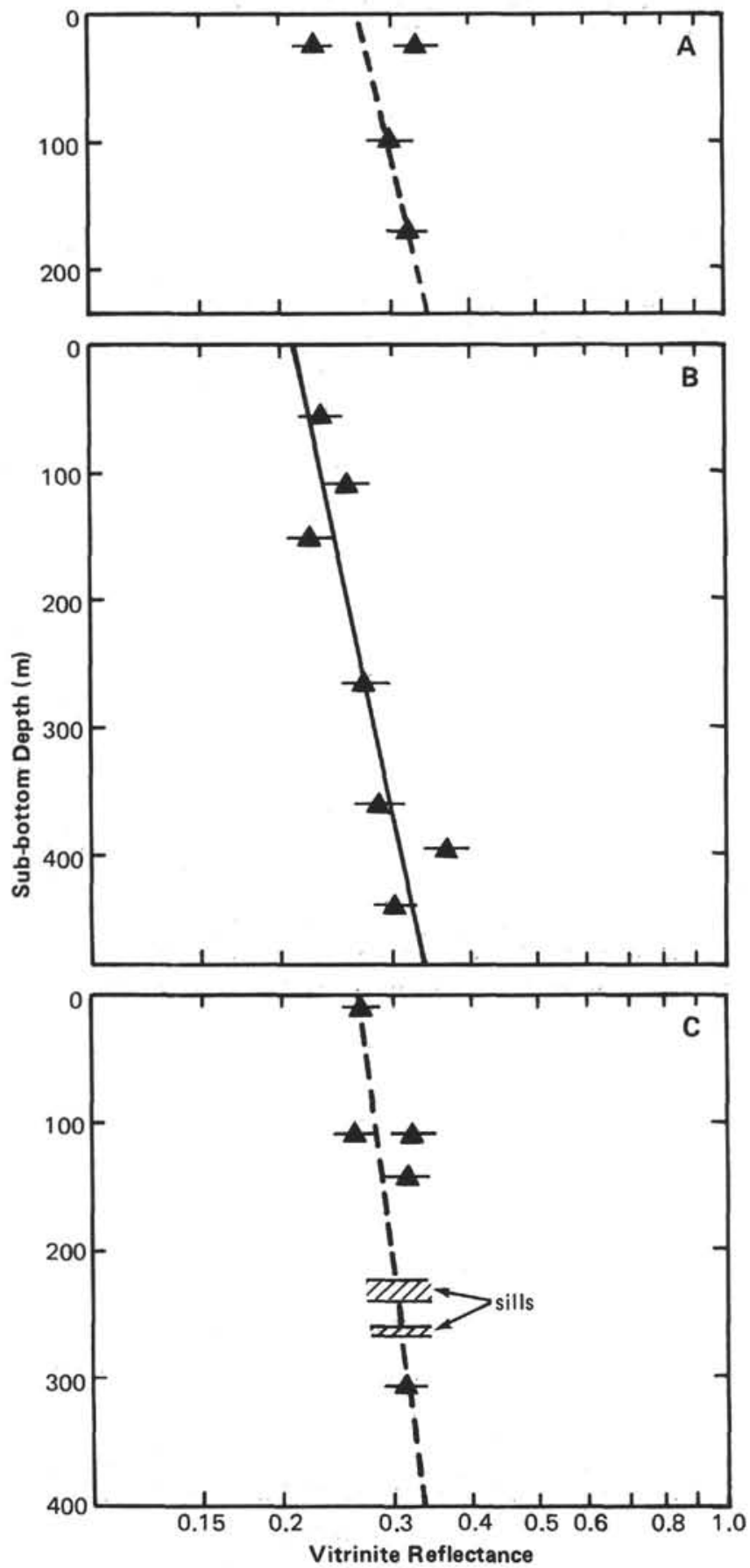

Figure 3. Profiles of vitrinite reflectance. (A. Hole 476. B. Hole 479. C. Hole 478.)

troleum generation. Philippi (1965), for instance, determined that oil generation occurred at about $115^{\circ} \mathrm{C}$ in Miocene sediments of California. Because the Gulf sediment is primarily Plio-Pleistocene, petroleum generation probably requires temperatures of at least $115^{\circ} \mathrm{C}$ or burial depths of 1100 meters. Sediment in the center of the Guaymas Basin is not that thick, but preliminary interpretation of seismic reflection lines indicates that sediment along the edge of the Guaymas Basin does exceed $1 \mathrm{~km}$ in thickness (J. R. Curray, personal communication, 1980).

\section{CONCLUSIONS}

1. The sediments from the Gulf of California exhibits fair-to-good potential as petroleum source rocks, although they are thermally immature. Although sediments lying within the present oxygen-minimum contain the greatest amount of organic matter, sediments below the oxygen minimum layer also contain sufficient organic matter to be considered potential source rocks.

2. Several kerogen-typing techniques indicate that the kerogen is Type II marine, implying that the sediments have the potential to generate oil. Possible retention of pyrolysate by the mineral matrix complicates analysis of kerogen type by pyrolysis.

3. Vitrinite reflectance and elemental analysis indicate that the kerogen is still at a very early stage of diagenesis. Temperature gradients imply that maturation at depths greater than $1 \mathrm{~km}$ is possible.

\section{ACKNOWLEDGMENTS}

The author wishes to thank P. R. Mommessin and B.R.T. Simoneit for their reviews. The staff of Shell's Geochemical Services, directed by J. R. Castaño, performed the analytical work. C. H. Hall and P. B. Borlase also provided valuable assistance by preparing the kerogen concentrates.

\section{REFERENCES}

Bordenave, M., Combaz, A., and Giraud, A., 1970. Influence de l'origine des matieres organiques et de leur degre d'evolution sur les produits de pyrolyse de kerogene. In Hobson, G. D., and Speers, G. C. (Eds.), Advances in Organic Geochemistry 1966: London (Pergamon), pp. 389-405.

Espitalié, J., LaPorte, J. L., and Madec, M., et al., 1977. Methode rapide de caracterisation des roches-meres, de leur potential petrolier et de leur degre d'evolution. Rev. Inst. Fr. Pet., 32:2342.

Espitalié, J., Madec, M., and Tissot, B., 1980. Role of mineral matrix in kerogen petrolysis: influence on petroleum generation and migration. Am. Assoc. Pet. Geol. Bull., 64:59-66.

Gransch, J. A., and Eisma, E., 1970. Characterization of the insoluble organic matter of sediments by pyrolysis. In Hobson, G. D., and Speers, G. C. (Eds.), Advances in Organic Geochemistry 1966: London (Pergamon), pp. 407-426.

Hood, A., Castaño, J. R., and Kendrick, J. W., 1976. Petroleumgenerating potential and thermal history of DSDP Leg 38 sediments. In Talwani, M., Udintsev, G., et al., Init. Repts. DSDP, 38: Washington (U.S. Govt. Printing Office), 801-804.

Kendrick, J. W., 1979. Geochemical studies of black clay from Leg 43, Deep Sea Drilling Project. In Tucholke, B. E., Vogt, P. R., et al., Init Repts. DSDP, 43: Washington (U.S. Govt. Printing Office), 633-642.

Kendrick, J. W., Hood, A., and Castaño, J. R., 1979. Petroleum-generating potential of sediments from Leg 47, Deep Sea Drilling Project. In Ryan, W. B. F., Sibuet, J.-C., et al., Init. Repts. DSDP , 47, Pt. 2: Washington (U.S. Govt. Printing Office), 547551.

Langseth, M. G., Jr., and Von Herzen, R. P., 1968. Heat flow through the floor of the world oceans. In Maxwell, A. E. (Ed.), The Sea (Vol. 4.): New York (John Wiley), 299-352.

Monin, J. C., Durand, B., Espitalié, J., et al., 1980. Experimental simulation of the natural transformation of kerogen at depth. In Douglas, A. G., and Maxwell, J. R. (Eds.), Advances in Organic Geochemistry 1979: London (Pergamon), pp. 517-530.

Philippi, G. T., 1965. On the depth, time, and mechanisms of petroleum generation. Geochim. Cosmochim. Acta, 29:1021-1049.

Tissot, B., Durand, B., Espitalié, J., et al., 1974. Influence of nature and diagenesis of organic matter in formation of petroleum. Am. Assoc. Pet. Geol. Bull., 58:499-506.

Tissot, B., and Welte, D. H., 1978. Petroleum Formation and Occurrence: Berlin (Springer-Verlag). 